\title{
The Role of International Organizations in Fostering Legitimacy in Dispute Resolution
}

\author{
Hugo Siblesz*
}

\begin{abstract}
This chapter addresses the role of international organizations in promoting the legitimacy in and effectiveness of alternative dispute resolution regimes. Defining legitimacy as the right to rule, allowing the parties to accept and comply with the rulings of dispute resolution regimes, the chapter argues that international institutions initially possess very little 'source legitimacy' or 'constitutive legitimacy' and are sometimes seen as lacking 'process legitimacy' or 'outcome legitimacy'. Using the framework of source, process, and outcome, the chapter argues that international organizations can play a strategic role in enhancing the source and process legitimacy of alternative dispute settlement regimes, and therefore the effectiveness of these regimes by embodying and endorsing in their work key values such as procedural justice, neutrality, and independence. The chapter further suggests that international organizations have an incredibly powerful role in supplementing the legitimacy of alternative dispute resolution regimes through avenues that are created by virtue of their institutional work and knowledge.
\end{abstract}

\section{Introduction}

This chapter provides a perspective on this theme from the Permanent Court of Arbitration (PCA), the first intergovernmental organization specifically created in 1899 to deal with State-related international disputes through arbitration, mediation, conciliation and fact-finding. ${ }^{1}$ Such State-related disputes refer

* Hugo Siblesz, Secretary General of the Permanent Court of Arbitration, hsiblesz@pca-cpa .org.

1 PCA is an intergovernmental organization established in 1899 under the Convention for the Pacific Settlement of International Disputes (opened for signature 29 July 1899, entered into force 4 September 190o) (The Hague Convention) 'with the object of facilitating an immediate recourse to arbitration for international differences'.

(C) ASIAN INFRASTRUCTURE INVESTMENT BANK (AIIB), 2019 | DOI:10.1163/9789004407411_007 
to disputes with a public element including, inter alia, contractual disputes involving State-owned or State-related entities, disputes involving international organizations, inter-State disputes and investor-State arbitrations under treaties for the protection of investment and investment laws. The PCA has administered nearly 200 of such investor-State cases, that number including approximately $70 \%$ of all known investor-State cases under the UNCITRAL Arbitration Rules. ${ }^{2}$

This chapter posits from the PCA's perspective that the relationship between international organizations and the promotion of effective dispute resolution would benefit from adding a crucial element in the middle of this equation, namely legitimacy. Specifically, this chapter will argue that legitimacy is the conduit through which international organizations involved in dispute resolution, such as the PCA, best promote the effectiveness of alternative dispute resolution regimes. It will focus on alternative dispute resolution mechanisms, ${ }^{3}$ although the same logic should apply to international judicial processes. ${ }^{4}$

\section{$2 \quad$ Legitimacy as the Cornerstone of Effective Dispute Resolution}

This section shall examine certain aspects of legitimacy concerning dispute resolution, namely (i) the definition of legitimacy, (ii) the relationship between legitimacy and the effectiveness of dispute resolution, and lastly (iii) the legitimacy deficit.

2 Uncitral, Arbitration Rules 2010. The UnCitral Arbitration Rules provide a comprehensive set of procedural rules upon which parties may agree for the conduct of arbitration proceedings arising out of their commercial relationship and are widely used in ad hoc arbitrations as well as administered arbitrations. The UNCITRAL Arbitration Rules cover all aspects of the arbitral process, providing a model arbitration clause, setting out procedural rules regarding the appointment of arbitrators and the conduct of arbitral proceedings, and establishing rules in relation to the form, effect and interpretation of the award. At present, there exist three different versions of the Arbitration Rules: (i) the 1976 version; (ii) the 2010 revised version; and (iii) the 2013 version. For more details, please, see $<$ www.uncitral.org/uncitral/en/uncitral_texts/arbitration/2010Arbitration_rules.html> accessed 13 December 2018.

3 Alternative dispute resolution refers to any method of resolving disputes without litigation. Major forms of alternative dispute resolution include arbitration, mediation. See Legal Information Institute <www.law.cornell.edu/wex/alternative_dispute_resolution\#> accessed 13 December 2018.

4 In this context, the term 'international judicial processes' refer to resolution of disputes by means of litigation. 


\subsection{The Definition of Legitimacy}

As a preliminary definitional matter, it is helpful to look into the question of what is meant by the term 'legitimacy'. Although the term has been used in various ways, it generally refers to the right to rule, where ruling includes promulgating rules (and in the dispute resolution context, issuing decisions and awards), and attempting to secure compliance with them by attaching costs to noncompliance or benefits to compliance. ${ }^{5}$ To elaborate, legitimacy and the right to rule may be understood as the support for or acceptance of authority that is independent of the relevant constituency's support for any specific decision or policy that the institution produces. In the literature, this has been called 'content-independent support' or 'diffuse support'. 6

To translate this into the dispute resolution context, legitimacy allows parties to accept and comply with the rulings of dispute resolution regimes, regardless of whether the outcome is favourable or adverse to their interests, and not because they are forced to, or because the particular ruling appeals to them rationally. ${ }^{7}$ The literature on this subject generally distinguishes between normative legitimacy, namely whether the institution should have the right to rule, and sociological legitimacy, namely whether the institution is believed to have the right to rule. ${ }^{8}$ These two meanings of legitimacy are closely interconnected but distinct.

\subsection{The Relationship between Legitimacy and the Effectiveness of Alternative Dispute Resolution}

As one could imagine, it is immensely powerful and stabilizing for an institution to enjoy support that is not contingent on self-interest, coercion, or rational persuasion. This is because what is in the self-interest changes according to circumstances, any threat of coercion may not always be credible, and people often disagree on what is or is not rational. ${ }^{9}$

This brings us to the second half of the equation, namely the relationship between legitimacy and the effectiveness of alternative dispute resolution. Having legitimacy would, no doubt, increase the effectiveness of a particular alternative dispute resolution regime by increasing compliance with decisions and awards, increasing stable and consistent participation in the dispute

5 Buchanan and Keohane, 2006.

6 Easton 1965, 278; ibid, 159; Shany, 'Stronger Together' 2018, 354-56, citing Clark 2011, 123-25.

7 Buchanan and Keohane 2006, 158.

8 Ibid, 158; Bodansky 2013, 326-27; Shany, Assessing the Effectiveness of International Courts 2014, 137 .

9 Buchanan and Keohane 2006, 159. 
settlement mechanism, and assisting in the development and further legitimization of the set of norms that constitute the regime. ${ }^{10}$ Extrapolating this into the economic sphere, which is obviously relevant in the context of work of multilateral development banks, such as the Asian Infrastructure Investment Bank, this lowers the cost of doing business globally (where resort to national courts is not always a possibility), promotes economic participation, and increases commercial stability and predictability.

\subsection{The Legitimacy Deficit}

This fully-fledged measure of legitimacy is somewhat of a rare commodity. Indeed, it has been recognised that intergovernmental institutions and international organizations, including alternative dispute resolution regimes, often suffer from a legitimacy deficit. ${ }^{11}$ Many of these institutions, to borrow the terminology from existing literature, ${ }^{12}$ suffer from a lack of initial "legitimacy capital' for several reasons. ${ }^{13}$

Firstly, such institutions, including alternative dispute settlement regimes, initially possess very little 'source legitimacy'14 or 'constitutive legitimacy'.15 To be sure, in the absence of a global demos to represent the interests of private persons, the legitimacy of international institutions has for a long time been considered largely through the prism of State consent. This ignores that States, although formally equal, ${ }^{16}$ are in fact unequal in terms of geopolitical power. This raises the question whether the consent given by smaller or weaker States is indeed voluntary under all circumstances.

Second, such institutions, including alternative dispute settlement regimes, are also sometimes seen as lacking 'process legitimacy'. ${ }^{17}$ In the absence of well-established and entrenched procedures and traditions, such as Codes of Civil or Criminal Procedure, the de-legitimization of authority occurs when certain procedural decisions are considered to be inadequate or unfair.

Third, if one is already working off a weak foundation of legitimacy, and a particular alternative dispute resolution regime produces certain outcomes

\footnotetext{
$10 \quad$ Shany, 'Stronger Together' 2018, 137.

11 Wolfrum 2008, 2-3.

12 Shany, Assessing the Effectiveness of International Courts 2014, 145.

13 Ibid.

14 Wolfrum 2008, 6 ('Authority can be legitimated by its source of origin. For public international law legitimacy rests - at least according to the traditional view - in the consent of the States concerned').

15 McDermott and Elmaalul 2017, 229.

16 On the doctrine of sovereign equality of states see, eg United Nations Charter, art 2(1); Kelsen 1944, 207-20; Kokott 2011.

17 McDermott and Elmaalul 2017, 229.
} 
that the relevant constituency does not consider to be adequate, then this may in the long run lead to an erosion of its 'outcome legitimacy', ultimately compromising the effectiveness of dispute resolution systems.

International Organizations Promote the Legitimacy and, Thereby, the Effectiveness of Alternative Dispute Resolution Regimes

Faced with this legitimacy deficit, therefore, international organizations involved in dispute resolution play a vital role in promoting and fostering the legitimacy, and thereby, the effectiveness of the regimes for which they have responsibility. Which brings us to the first part of the equation mentioned at the beginning of this chapter, namely the relationship between international organizations and the legitimacy of alternative dispute resolution regimes.

Here, the use of the framework of source, process, and outcome legitimacy seems to be appropriate. Leaving aside the question of outcome legitimacy with regard to which the PCA as an arbitral institution that supports and provides the infrastructure for the decision-makers, which is to say, the tribunal, has limited influence. But international organizations like the PCA can enhance the source and process legitimacy of alternative dispute settlement regimes, and therefore the effectiveness of these regimes by embodying and endorsing in their work key values such as procedural justice, neutrality, and independence. ${ }^{18}$ These constitutive elements not only foster normative legitimacy by bolstering the democratic authority and neutrality of the system, but also its sociological legitimacy, which comes from being associated with established and well-respected regimes.

As a result of the legitimacy crises ${ }^{19}$ experienced by both investor-State and State-to-State dispute settlement regimes such as the World Trade Organization, some States are considering ${ }^{20}$ alternative methods of dispute resolution, whether it is a multilateral investment court or ad hoc inter-State panels. In this context, these States have explicitly considered the possibility of using existing courts of arbitration such as the PCA, to administer these novel methods of dispute resolution. ${ }^{21}$ This option not only ensures that the relevant panel,

$18 \quad$ Tyler 2011.

19 S Franck 2005, 1521.

$20 \quad$ UnCitRAL, 'Draft Report on Investor-State Dispute Settlement Reform' 2018.

21 Council of the European Union, 'Multilateral Court for the Settlement of Investment Disputes' 2018 (noting that the Convention 'should not exclude the possibility for the court to rely on the secretarial support of an existing international organization, nor to be integrated into the structure of any such organization at a later stage'); Draft EU-Japan Economic Partnership Agreement, art 21.25 (2) ('Notwithstanding paragraph 1, the Parties 
court, or tribunal is provided with high-quality secretarial and administrative assistance. It also, as some commentators have noted, provides the new dispute settlement regime with the benefit of the brand of the court, which increases the symbolic power of the decision and the reputational costs of non-compliance, in other words, legitimacy. ${ }^{22}$

These constitutive elements also enhance the actual and perceived neutrality of the dispute resolution regimes that these international organizations administer, and thereby, their source legitimacy. At the PCA there is a wide and geographically and politically diverse group of 121 Contracting Parties. Their participation in the governance of the PCA by necessity creates a de-politicized policy framework within which the International Bureau of the PCA is able to administer disputes that sometimes involve sensitive and hot-button political issues. ${ }^{23}$ The PCA and its staff have no choice but to be completely neutral in respect of issues arising in connection with proceedings under its auspices.

A second element which enhances process legitimacy is the special legal status and immunity from national courts that international organizations like the PCA enjoy through headquarters and host country agreements. Through this network of agreements, they are able to ensure independence in the administration of both interstate disputes and so-called mixed arbitrations, which enhances the process legitimacy dispute resolution regime.

On the one hand, states may be less comfortable with private or commercially focused institutions, whereas private parties can be reassured, by the

may agree to jointly entrust an external body with providing support for certain administrative tasks for the dispute settlement procedure under this Chapter')

22 Vidigal 2018.

23 The PCA has a three-part organizational structure consisting of an Administrative Council that oversees its policies and budgets, a panel of independent potential arbitrators known as the Members of the Court, and its Secretariat, headed by the Secretary-General. Contracting Parties' diplomatic representatives accredited to the Netherlands comprise the Administrative Council, under the chairmanship of the Netherlands Minister of Foreign Affairs. This body, in consultation with the Secretary-General, shapes the policy of the organization. It provides general guidance on the work of the PCA, and supervises its administration, budget and expenditure. The PCA's Secretariat - the International Bureau-consists of an experiences team of legal and administrative staff of various nationalities. It is headed by its Secretary-General. The bureau provides administrative support to tribunals and commissions, serving as the official channel of communications and ensuring safe custody of documents. The International Bureau provides services such as financial administration, logistical and technical support for meetings and hearings, travel arrangements, and general secretarial and linguistic support. It also provides administrative support to tribunals or commissions conducting PCA dispute settlement proceedings outside the Netherlands. See The Hague Convention arts 22, 28. For more details also see $<$ https://pca-cpa.org/en/about/>. 
immunity that international organizations like the PCA enjoy, that the proceedings will not be subject to political pressure. Furthermore, the diversity of views represented by the PCA's 121 Contracting Parties necessarily requires the organization to maintain a position of neutrality. ${ }^{24}$ As an example, the PCA has taken no position on whether the present Investor-State Dispute Settlement System (ISDS) should or should not be replaced by an entirely different structure. The PCA holds the position that it is up to the primary stakeholders to determine what kind of mechanism or structure they deem fit for settlement of disputes arising out of agreements that they conclude.

It should be clarified at this point that the immunity that the PCA as an organization enjoys under its Headquarters Agreement with the Netherlands does not render awards in PCA-administered mixed arbitrations seated in the Netherlands immune from the jurisdiction of Dutch courts. Similarly, with respect to PCA-administered mixed arbitrations that are seated in other jurisdictions, the national courts of the legal seat may exercise jurisdiction over any enforcement, exequatur, ${ }^{25}$ and set aside proceedings mitigated as appropriate by any relevant host-country or headquarters agreement that is in place. This qualification, however, can be seen to promote rather than hinder the legitimacy of the dispute resolution regime.

In point of fact, one would imagine that, regardless of where an arbitration is seated, it would have to be subject to some court's supervisory jurisdiction. Indeed, it would be inconceivable that developed jurisdictions would allow semi-judicial structures to operate without any method of ensuring that basic procedural standards have been respected in those proceedings. Moreover, there are good practical reasons for parties in fact to want to subject themselves to the supervisory jurisdiction of the courts of the seat in order to ensure the enforceability of the award, or even to forestall the unexpected intervention of other national courts. Consequently, the circumscribed supervisory authority of national courts over proceedings administered by international organizations such as the PCA, it may be argued, actually increases the procedural legitimacy and effectiveness of dispute resolution proceedings.

24 Additional guarantee of the PCA's neutrality is its funding structure: under art 29 of The Hague Convention 'the expenses of the Bureau shall be borne by the Signatory Powers in the proportion fixed for the International Bureau of the Universal Postal Union'. In addition, the PCA maintains its own independent budget by providing registry services to the parties to arbitral proceedings on a remunerated basis.

25 Exequatur is a written official recognition and authorization of a consular officer issued by the government to which he is accredited. See Merriam-Webster Dictionary <www. merriam-webster.com/dictionary/exequatur> accessed 13 December 2018. 
As a third aspect, this chapter argues that international organizations involved in dispute resolution provide alternative dispute resolution regimes with crucial process legitimacy by, among other things, contributing to procedural consistency. Arbitral institutions like the PCA can provide experienced staff and institutionalized procedures that are specially designed to assist tribunals from across the cases that it administers in promoting procedural justice, stability, and consistency. The PCA Secretary-General's responsibility as appointing authority under, notably, the UNCITRAL Rules, ${ }^{26}$ which includes ruling on any arbitrator challenges, is one such example.

Externally, international organizations involved in dispute resolution participate in and support the work of other international organizations and, through the mutual exchange of ideas, expertise, and experience, develop and strengthen the procedural consistency and foundation that undergirds the dispute resolution system, thereby increasing its legitimacy. The PCA, for example, participates in and brings its own experience as an observer to the UNCITRAL's work on the possible reform of the ISDS. In its capacity as an observer to the United Nations (UN), during the UN General Assembly's Sixth Committee's ${ }^{27}$ consideration of the International Law Commission's (ILC) report, the PCA also provides information on various issues, including evidence before international courts and tribunals, provisional application of treaties, and the protection of the atmosphere.

To clarify, this chapter does not opine on the issue of substantive consistency and what the ILC describes as 'the normative conflict that is endemic to international law', which arises from 'the spontaneous, decentralised and non-hierarchical nature of international law-making. ${ }^{28}$ Rather, it is a reference to the principles of procedural justice that Thomas Franck, H.L.A. Hart, and

26 UNCITRAL, Arbitration Rules 2010, art 6(1).

27 The Sixth Committee is the primary forum for the consideration of legal questions in the General Assembly. All of the UN member states are entitled to representation on the Sixth Committee as one of the main committees of the General Assembly. For more details please see <www.un.org/en/ga/sixth/> accessed 13 December 2018. The PCA acts as an observer to the Sixth Committee, participating in its work and providing information on various issues.

28 ILC, 'Report on Fragmentation of International Law' 2006. Normative conflict as defined by the ILC implicates four types of relationships that lawyers have to deal with, namely the relations between special and general law, relations between prior and subsequent law, relations between laws at different hierarchical levels, and relations of law to its 'normative environment' more generally (at para 18). Further, according to the ILC, 'lawyers have always to deal with heterogeneous materials at different levels of generality and with different normative force'. 
other legal scholars have cited as equally (if not more) crucial to ensuring the fairness and legitimacy of a particular dispute resolution process. ${ }^{29}$

The decades' worth of institutional knowledge, continuity of practice, and personnel experience that the PCA brings to alternative dispute resolution proceedings, both through administration of cases and the sharing of knowledge within the relevant legal communities, is, therefore, another important means by which the PCA contributes to the process legitimacy of such regimes.

\section{$4 \quad$ Examples from the PCA's Practice}

Some examples illustrate how the PCA has been an active participant in developing novel approaches to alternative dispute resolution, these approaches having subsequently helped to increase the effectiveness of the system as a whole.

As early as 1934, decades before the explosion of bilateral investment treaties and investor-State dispute settlement, ${ }^{30}$ the PCA administered the first mixed arbitration opposing a private entity and a State in Radio Corporation of America v. China. ${ }^{31}$ This dispute, which arose out of a contract between the parties for the operation of a radio telegraphic circuit for commercial communications between China and the United States, was submitted to arbitration administered by the PCA. The award rendered was in favour of China, with costs allocated between the parties. This case was followed by others and has set an important precedent for disputes between private parties and States, including modern-day investment proceedings, which are, as we know, commonplace today.

In another example, in December 2000, the Eritrea-Ethiopia Claims Commission was created pursuant to an Agreement signed between the Governments of the State of Eritrea and the Federal Democratic Republic of Ethiopia. ${ }^{32}$ The registry for this Commission was entrusted to the PCA. ${ }^{33}$ This Claims Commission was to decide through binding arbitration all claims for loss, damage or injury by one Government or its nationals against the other Government or its nationals that arose out of violations that occurred during the 20-year Eritrean-Ethiopian War. In total, the Commission delivered 15

29 Lind and Tyler 1988; T Franck 1990, 52; Hart 2012, 164.

30 Binder 2009; Hobér 2015;

$31 \quad$ PCA, USA $v$ China 1934.

32 Agreement Between the Government of the Federal Democratic Republic of Ethiopia and the Government of the State of Eritrea.

33 See PCA, 'Eritrea-Ethiopia Claims Commission'. 
partial and final awards on liability and concluded its work in 2009, when it delivered its final awards on damages.

Most recently, the PCA administered the first two arbitrations ${ }^{34}$ brought under the Bangladesh Accord, ${ }^{35}$ an agreement between global brands and trade unions created in the aftermath of the Rana Plaza building collapse, ${ }^{36}$ to establish a fire and building safety programme for workers in the textile industry in Bangladesh. These arbitrations, which were recently settled between the parties, were among the first of their kind in dealing with issues relating to corporate social responsibility, and in particular, workplace safety.

A truly exceptional case was administered by the PCA in the context of the $\mathrm{UN}$-administered political process dealing with the conflict between the central government of Sudan and the South Sudan Liberation Movement/Army, the so-called Abyei-Arbitration. ${ }^{37}$ An award was rendered in record time, considering the complexity of the case, establishing what is now the border between Sudan and South Sudan. At the time it was an essential element to allow the referendum on the future of South Sudan going forward. This case provides proof of the flexibility of the instrument of arbitration, committing to a binding result a State and an entity that has been fighting that State politically and militarily for a number of years.

There are many other forms of alternative dispute settlement mechanisms that the PCA has administered with great success and which shall not be described in full detail here. They include, among others, the first compulsory conciliation proceedings under Annex v of UNCLOS ${ }^{38}$ between Australia and Timor-Leste, the South Pacific Regional Fisheries Management Organization Review Panel, and the Tribunal for the Bank of International Settlements. ${ }^{39}$

\section{5}

\section{Conclusion}

This chapter concludes by returning to the equation that was posited at the outset. International organizations have an incredibly powerful role in supplementing the legitimacy of alternative dispute resolution regimes through

34 PCA, Industriall Global Union and UNI Global Union v Respondent (2016-36) 2016; PCA, IndustriALL Global Union and UNI Global Union v Respondent (2016-37) 2016.

35 Accord on Fire and Building Safety in Bangladesh.

36 Manik and Yardley 2013; Burke 2014; Westervelt 2014; Westerman 2017; Safi and Rushe 2018.

37 PCA, Abyei Arbitration 2008; Daly 2010, 801-23.

38 United Nations Convention on the Law of the Sea, Annex v.

39 PCA, Reineccius $v$ Bank for International Settlements 2000; PCA, Timor Leste $v$ Australia 2016; PCA, Review Panel 2018. 
avenues that are created by virtue of their institutional work and knowledge. Alternative dispute resolution regimes often face legitimacy deficits by virtue of their constitutional structure-deficits which can significantly hinder their operations, including the efficient and effective resolution of international disputes. Through the currency of legitimacy, however, international organizations involved in dispute resolution can significantly assist these regimes in ensuring that novel disputes, whether in terms of subject matter, method of dispute resolution, or the nature of the parties, are settled efficiently and effectively notwithstanding the absence of structurally-derived legitimacy or longstanding practice.

\section{Reference List}

EU-Japan Economic Partnership Agreement (EU-Japan) (adopted in 12 December 2018, entered into force on 1 February 2019), <http://ec.europa.eu/trade/policy/in -focus/eu-japan-economic-partnership-agreement/> accessed on 19 February 2019. Accord on Fire and Building Safety in Bangladesh (2013).

Agreement between the Government of the Federal Democratic Republic of Ethiopia and the Government of the State of Eritrea (The Algiers Agreement) (signed 12 December 2000) 2138 UNTS 94; 40 ILM 260 (2001).

Binder Ch, International Investment Law for the 21st Century: Essays in Honour of Chrisoph Schreuer (OUP 2009).

Bodansky D, 'Legitimacy in International Law and International Relations' in Jeffrey L. Dunoff and Mark A. Pollack (eds), Interdisciplinary Perspectives on International Law and International Relations: The State of the Art (CUP 2013).

Buchanan A and Keohane R, 'The Legitimacy of Global Governance Institutions' (2006) 20 Ethics \& International Affairs.

Burke J, 'Rana Plaza: one year on from the Bangladesh factory disaster' The Guardian (Bangladesh, 19 April 2014) <www.theguardian.com/world/2014/apr/19/rana-plaza -bangladesh-one-year-on> accessed 22 February 2019.

Conciliation (Timor Lestev Australia) [2016] PCA Case No. 2016-10.

Council of the European Union, 'Negotiating Directives for a Convention Establishing a Multilateral Court for the Settlement of Investment Disputes' (1 March 2018) 12981/17 ADD 1 DCL 1.

Clark T S, 'The Public and Judicial Independence' in Bruce Peabody (ed), The Politics of Independence: Courts, Politics and the Public (The Johns Hopkins University Press 2011).

Daly B, 'The Abyei Arbitration: Procedural Aspects of an Intra-state Border Arbitration' (2010) 23 Leiden Journal of International Law. 
Delimiting Abyei Area (Sudanv The Sudan People's Liberation Movement/Army) [2010] PCA Case No. 2008-07.

Easton D, A Systems Analysis of Political Life (John Wiley \& Sons 1965).

The Federal Democratic Republic of Ethiopia v the State of Eritrea ("Eritrea") [2001] PCA Case No. 2001-2.

Franck S, 'The Legitimacy Crisis in Investment Treaty Arbitration: Privatizing Public International Law Through Inconsistent Decisions' (2005) 73 Fordham Law Review 1521.

Franck T, The Power of Legitimacy among Nations (OUP 1990).

The Hague Convention for the Pacific Settlement of International Disputes (open for signature 29 July 1899, entered into force 4 September 1900) 1 Bevans 230; 1 AJIL 103 (1907).

Hart H L A, The Concept of Law (OUP 2012).

Hobér K, 'Investment Treaty Arbitration and Its Future - If Any' (2015) 7 Yearbook on Arbitration and Mediation.

ILC, 'Report of the Study Group of the International Law Commission on Fragmentation of International Law: Difficulties Arising from the Diversification and Expansion of International Law' (1 May-9 June and 3 July-11 August 2006) UN Doc A/CN.4/L.682.

IndustriALL Global Union and UNI Global Union v Respondent [2016] PCA Case No. 2016-36.

IndustriALL Global Union and UNI Global Union v Respondent [2016] PCA Case No. 2016-37.

Kelsen H, 'The Principle of Sovereign Equality of States as a Basis for International Organization' (1944) 53 The Yale Law Journal 207.

Kokott J, 'States, Sovereign Equality', Max Planck Encyclopaedia of Public International Law (OUP 2011).

Lind A and Tyler T, The Social Psychology of Procedural Justice (Springer 1988).

Manik J and Yardley J, 'Building Collapse in Bangladesh Leaves Scores Dead' New York Times (25 April 2013) <www.nytimes.com/2013/04/25/world/asia/bangladesh -building-collapse.html $>$ accessed on 21 February 2019.

McDermott Y and Elmaalul W, 'Legitimacy' in William A Schabas and Shannonbrooke Murphy (eds), Research Handbook on International Courts and Tribunals (Edward Elgar Publishing 2017).

Radio Corporation of America (USA v China) [1934] PCA Case No. 1934-01.

Reineccius and ors. al. v Bank for International Settlements [200o] PCA Case No. 2000-04.

Review Panel established under the Convention on the Conservation and Management of High Seas Fishery Resources in the South Pacific Oceans [2018] PCA Case No. 2018-13. 
Safi M and Rushe D, 'Rana Plaza, five years on: safety of workers hangs in balance in Bangladesh' The Guardian (Dhaka and New York, 24 April 2018) <www.theguardian .com/global-development/2018/apr/24/bangladeshi-police-target-garment -workers-union-rana-plaza-five-years-on> accessed 22 February 2019.

Shany Y, Assessing the Effectiveness of International Courts (OUP 2014).

Shany Y, 'Stronger Together? Legitimacy and Effectiveness of International Courts as Mutually Reinforcing or Undermining Notions' in Nienke Grossman and others (eds), Legitimacy and International Courts (CUP 2018).

Tyler T R, 'Procedural Justice and the Rule of Law: Fostering Legitimacy in Alternative Dispute Resolution' (2011) 4992 Yale Law School Faculty Scholarship Series <https:// digitalcommons.law.yale.edu/cgi/viewcontent.cgi?referer=https://www.google .com.hk/\&httpsredir=1\&chapter $=5983 \&$ context=fss_papers $>$ accessed 22 February 2019.

United Nations Charter (1945) (signed 26 June 1945, entered into force 24 October 1945) 1 UNTS XVI.

United Nations Convention on the Law of the Sea (UNCLOS) (opened for signature 10 December 1982, entered into force 16 November 1994) 1833 UNTS 396.

UNCITRAL, Arbitration Rules (as revised 2010), UNGA Res 65/22 (6 December 2010).

UNCITRAL, 'Draft Report of Working Group III (Investor-State Dispute Settlement Reform) on the Work of its Thirty-sixth Session' (6 November 2018) UN Doc A/CN.9/964.

United Nations Convention on the Law of the Sea (adopted 10 December 1982, entered into force 16 November 1994) 1883,1884 and 1885 UNTS 3 annex V.

Vidigal G, 'Making Regional Dispute Settlement Attractive: The "Court of Arbitration" Option' (ICSID 2018).

Westervelt A, 'Two years after Rana Plaza, have conditions improved in Bangladesh's factories?' The Guardian (24 April 2014) <www.theguardian.com/sustainable -business/2015/apr/24/bangladesh-factories-building-collapse-garment-dhaka -rana-plaza-brands-hm-gap-workers-construction> accessed 22 February 2019.

Westerman A, '4 Years After Rana Plaza Tragedy, What's Changed for Bangladeshi Garment Workers?' NPR (30 April 2017) <www.npr.org/sections/parallels /2017/04/30/525858799/4-years-after-rana-plaza-tragedy-whats-changed-for -bangladeshi-garment-workers $>$ accessed 22 February 2019.

Wolfrum R, 'Legitimacy of International Law from a Legal Perspective: Some Introductory Considerations' in Rüdiger Wolfrum and Volker Röben (eds), Legitimacy in International Law (Springer 2008). 